\title{
Do submesoscale frontal processes ventilate the oxygen minimum zone off Peru?
}

Article in Geophysical Research Letters · August 2016

DOI: 10.1002/2016GL070548

READS

7

6 authors, including:

Sören Thomsen

Helmholtz Centre for Ocean Research Kiel

13 PUBLICATIONS 11 CITATIONS

SEE PROFILE

Anja Engel

Helmholtz Centre for Ocean Research Kiel

105 PUBLICATIONS 2,801 CITATIONS

SEE PROFILE
V. Echevin

Pierre and Marie Curie University - Paris 6

69 PUBLICATIONS 883 CITATIONS

SEE PROFILE 


\section{Geophysical Research Letters}

\section{RESEARCH LETTER \\ 10.1002/2016GL070548 \\ Do submesoscale frontal processes ventilate the oxygen minimum zone off Peru?}

Key Points:

- Observed subduction of oxygenated surface water in a submesoscale filament off Peru

- Submesoscale-permitting model simulations confirm that subduction occurs in filaments off Peru

- Lagrangian float diagnostics suggest that $50 \%$ of the newly upwelled water is subducted

Correspondence to:

S. Thomsen,

sthomsen@geomar.de

\section{Citation:}

Thomsen S., T. Kanzow, F. Colas, V. Echevin, G. Krahmann, and A. Engel (2016), Do submesoscale frontal processes ventilate the oxygen minimum zone off Peru?, Geophys. Res. Lett., 43, doi:10.1002/2016GL070548.

Received 21 JUL 2016 Accepted 22 JUL 2016 Accepted article online 27 JUL 2016

\section{Introduction}

\author{
S. Thomsen ${ }^{1}$, T. Kanzow ${ }^{1,2}$, F. Colas $^{3}$, V. Echevin ${ }^{3}$, G. Krahmann ${ }^{1}$, and A. Engel ${ }^{1}$ \\ ${ }^{1}$ GEOMAR Helmholtz Centre for Ocean Research, Kiel, Germany, ${ }^{2}$ Alfred-Wegener-Institute Helmholtz Centre for Polar and \\ Marine Research, Bremerhaven, Germany, ${ }^{3}$ IRD, Paris, France
}

\begin{abstract}
The Peruvian upwelling system encompasses the most intense and shallowest oxygen minimum zone $(\mathrm{OMZ})$ in the ocean. This system shows pronounced submesoscale activity like filaments and fronts. We carried out glider-based observations off Peru during austral summer 2013 to investigate whether submesoscale frontal processes ventilate the Peruvian OMZ. We present observational evidence for the subduction of highly oxygenated surface water in a submesoscale cold filament. The subduction event ventilates the oxycline but does not reach $\mathrm{OMZ}$ core waters. In a regional submesoscale-permitting model we study the pathways of newly upwelled water. About $50 \%$ of upwelled virtual floats are subducted below the mixed layer within 5 days emphasizing a hitherto unrecognized importance of subduction for the ventilation of the Peruvian oxycline.
\end{abstract}

The Peruvian upwelling region, being one of the four major eastern boundary upwelling systems, is characterized by pronounced mesoscale and submesoscale variability such as eddies and filaments [Capet et al., 2008a; McWilliams et al., 2009]. This variability plays a key role for the offshore and downward export of physical and biogeochemical properties from the productive surface coastal region [Rossi et al., 2008, 2009; Lathuilière et al., 2010; Gruber et al., 2011; Nagai et al., 2015]. Submesoscale processes operate on horizontal scales of less than the Rossby radius of deformation ranging from fronts and filaments $\mathrm{O}(1-10 \mathrm{~km})$ to mixed layer instabilities $\mathrm{O}(1 \mathrm{~km})$ and symmetric instabilities $\mathrm{O}(100 \mathrm{~m})$ [e.g., Haine and Marshall, 1998; Boccaletti et al., 2007; Thomas et al., 2008; McWilliams et al., 2009, 2015; McWilliams, 2016]. Here we focus on the upper part of this regime, submesoscale filaments and fronts. Submesoscale frontal processes drive large vertical velocities and enhance vertical tracer fluxes in the upper ocean [Mahadevan and Tandon, 2006; Capet et al., 2008b; Thomas et al., 2008]. The highly productive Peruvian upwelling region encompasses the most intense and shallowest oxygen minimum zone (OMZ) in the ocean [Karstensen et al., 2008] with oxygen concentrations below $1 \mu \mathrm{mol} / \mathrm{L}$ in its core [Revsbech et al., 2009; Kalvelage et al., 2013]. The oxycline (i.e., the transition from the oxygenated surface waters to the $\mathrm{OMZ}$ ) is often very shallow (around $30 \mathrm{~m}$ ) near the coast [Hamersley et al., 2007]. Due to the vicinity of the oxygenated mixed layer and the OMZ waters below, vertical advective motion driven by submesoscale frontal dynamics might be a key process for the vertical supply of oxygen into the OMZ. While a large number of observational and model studies have addressed the role of upwelling filaments for the offshore transport of physical and biogeochemical properties in the Californian [Flament et al., 1985; Strub et al., 1991; Kadko et al., 1991; Barth et al., 2002; Nagai et al., 2015], Iberian/Canarian [Barton et al., 2004; Cravo et al., 2010], and Benguela upwelling systems [Lutjeharms et al., 1991], the Peru region has received less attention. Pietri et al. [2013] use glider observations to investigate the formation of submesoscale hydrographic structures due to mesoscale stirring. The authors hypothesize that subduction might also be important for the formation of fine-scale structures. Yet no observational evidence for the subduction of highly oxygenated surface waters off Peru driven by submesoscale processes has been presented. Here we investigate whether submesoscale frontal processes ventilate the Peruvian OMZ. To this end we make use of high-resolution glider-based observations carried out off Peru near $14^{\circ} \mathrm{S}$ in austral summer 2013 during active upwelling. Additionally, submesoscale-permitting regional ocean circulation model output is analyzed to put the instantaneous short-term observations in a broader spatial and temporal context.
○2016. American Geophysical Union. All Rights Reserved. 

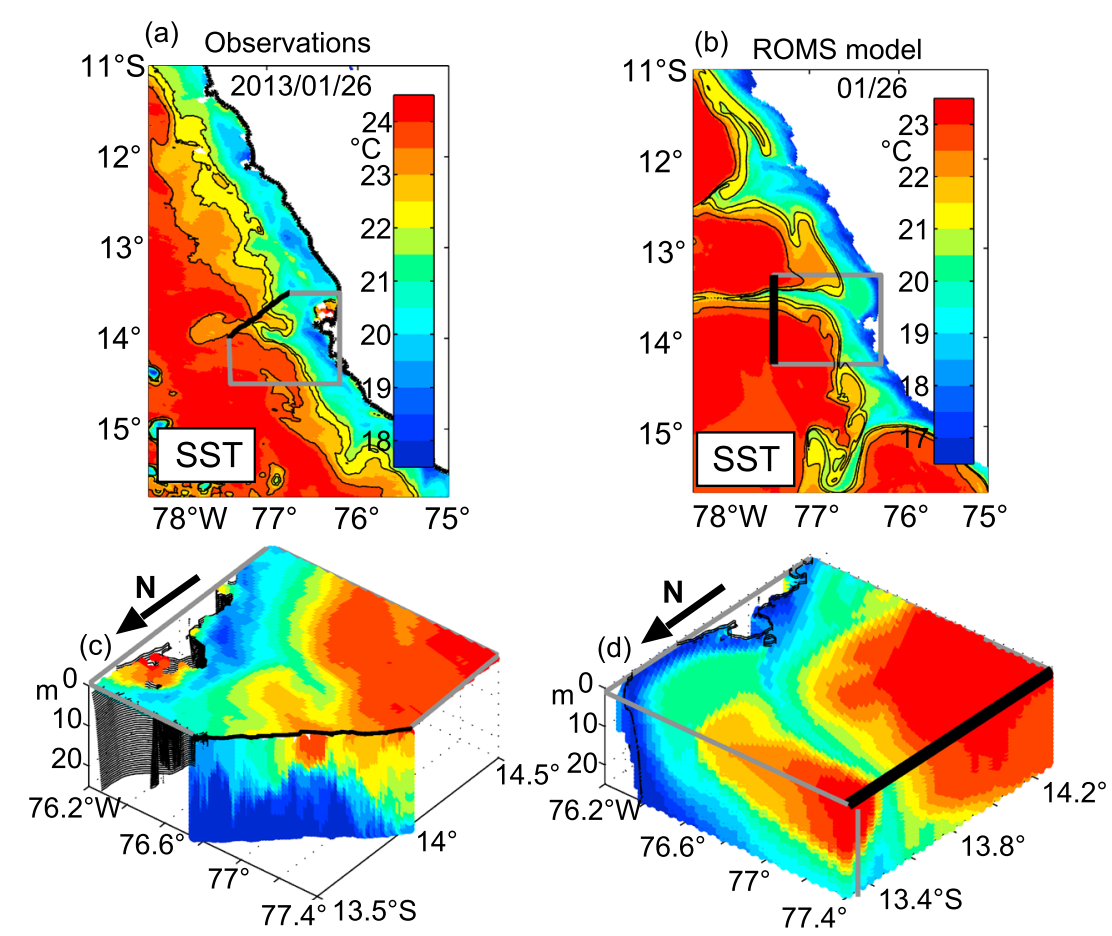

Figure 1. Snapshots of (a, c) observed (MODIS Terra $1 \mathrm{~km}$ ) and (b, d) modeled (ROMS $2 \mathrm{~km}$ ) SST and three-dimensional near-surface temperature fields associated with a submesoscale cold filament off Peru. The glider transect is marked by a black line in Figures 1a and 1c and the SST box in grey. Note the different color bars in Figures 1a and 1c, and 1b and 1d.

\section{Observational and Model Data}

\subsection{Glider and Satellite Observations}

The observational part of this study is based on high-resolution measurements of one Slocum glider collected during a multiplatform observational campaign in January and February 2013 off Peru between $12^{\circ}$ and $14^{\circ} \mathrm{S}$ in the framework of the interdisciplinary collaborative research center SFB 754 "Climate-Biogeochemistry Interactions in the Tropical Ocean" funded by the Deutsche Forschungsgemeinschaft. Temperature, salinity, oxygen, and fluorescence (chlorophyll) measurements of the upper $70 \mathrm{~m}$ at a horizontal and vertical resolution of about $1 \mathrm{~km}$ and $1 \mathrm{~m}$, respectively, are shown. A detailed description of the data processing and calibration is presented in Thomsen et al. [2016]. The glider goes back and forth every $4-5$ days along a $100 \mathrm{~km}$ transect perpendicular to the coast near $13^{\circ} 30^{\prime} \mathrm{S}$ (Figure 1a). The transects capture the signature of an evolving submesoscale cold filament between 21 January and 11 February 2013 (Figures 1 and 2). Snapshots of sea surface temperature (SST) Moderate Resolution Imaging Spectroradiometer (MODIS) Aqua/Terra (http://oceandata.sci.gsfc.nasa.gov) are used to put the glider measurements into a regional context.

\subsection{Regional Ocean Model}

A regional ocean model quasi-equilibrium simulation (ROMS) [Shchepetkin and McWilliams, 2005, 2009] of the Peruvian upwelling region is used to investigate the pathways of newly upwelled water. The model domain spans from $16^{\circ} \mathrm{S}$ to $4.5^{\circ} \mathrm{S}$ along the coast to about $880 \mathrm{~km}$ offshore at a horizontal resolution of $2.2 \mathrm{~km}$ and 42 terrain-following vertical levels (sigma coordinates). It is nested offline in a Peru-Chile model with $7.5 \mathrm{~km}$ horizontal resolution as in McWilliams et al. [2009] and uses boundary conditions from the climatological simulation analyzed by Colas et al. [2012]. The model is forced with the Scatterometer Climatology of Ocean Winds [Risien and Chelton, 2008] and the Comprehensive Ocean Atmosphere Data Set surface fluxes. The 7.5 $\mathrm{km}$ model is initialized by the Simple Ocean Data Assimilation model at $1 / 4^{\circ}$ and run for a total of 8 years [Colas et al., 2012]. After a 3 year spin-up, initial state and boundary conditions from the $7.5 \mathrm{~km}$ model are interpolated on the $2.2 \mathrm{~km}$ grid and run for another 5 years. The last 4 years of this $2.2 \mathrm{~km}$ run are analyzed.

The model shows a realistic near-coastal circulation with a mean poleward Peru-Chile Undercurrent of $0.15 \mathrm{~m} / \mathrm{s}$ centered at $150 \mathrm{~m}$ depth at $15^{\circ} \mathrm{S}$ (not shown), which is comparable to observational estimates of $0.14 \mathrm{~m} / \mathrm{s}$ between $12^{\circ}$ and $15^{\circ} \mathrm{S}$ [Chaigneau et al., 2013]. The model simulates pronounced submesoscale 

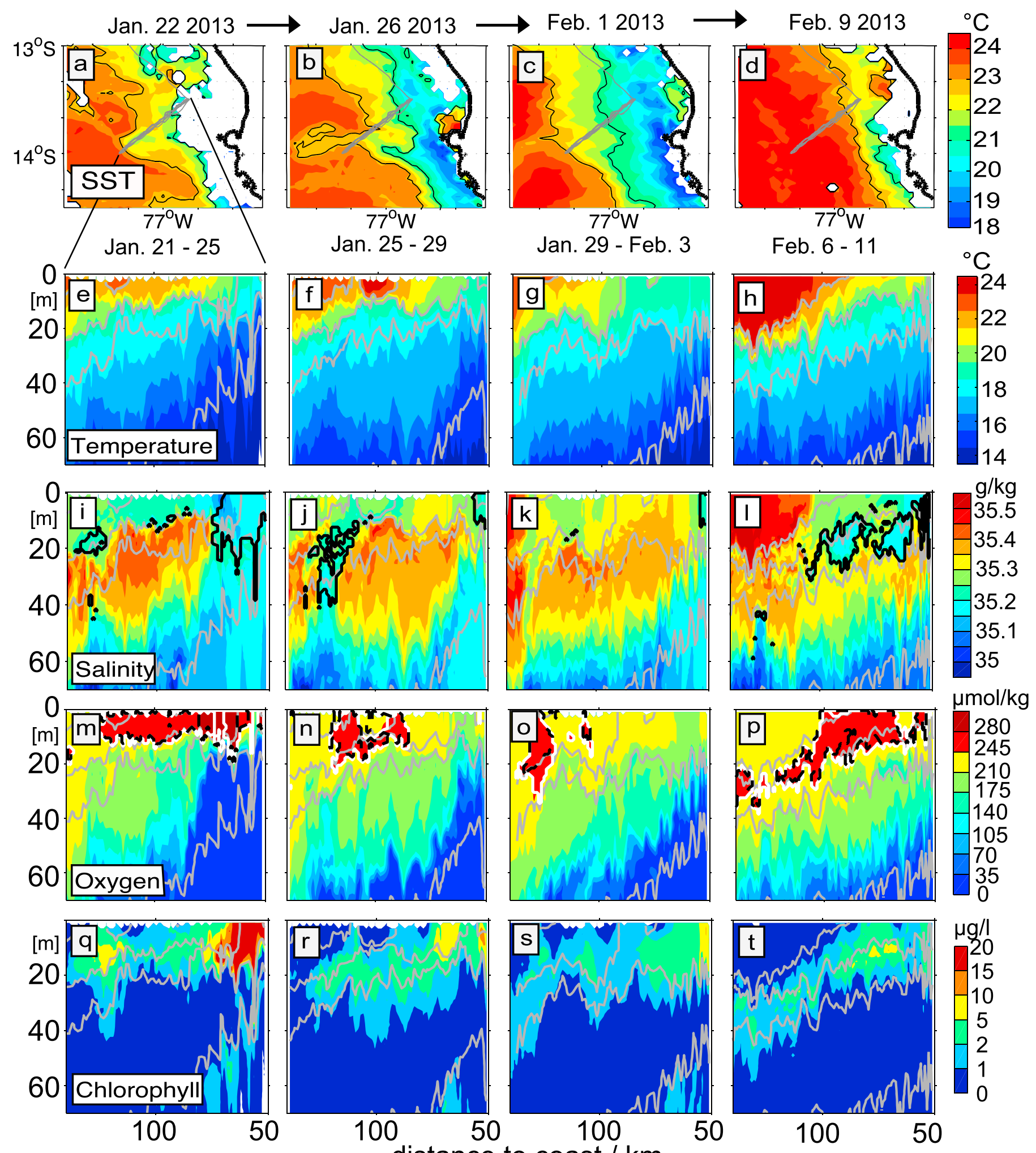

Figure 2. (a-d) The SST (MODIS Aqua/Terra $4 \mathrm{~km}$ ) associated with the formation and decay of a submesoscale cold filament off Peru in January/February 2013 is shown. Repeated glider transect of the $(e-h)$ near-surface temperature, $(i-l)$ salinity, $(m-p)$ oxygen, and $(q-t)$ chlorophyll distribution are shown. Newly upwelled water of low temperature $\left(16.75\right.$ to $\left.20^{\circ} \mathrm{C}\right)$ and low salinity $(35.05$ to $35.24 \mathrm{~g} / \mathrm{kg})$ and medium temperature $\left(17.5\right.$ to $\left.22^{\circ} \mathrm{C}\right) / \mathrm{high}$ oxygen $(>245 \mu \mathrm{mol} / \mathrm{L})$ are marked by black and white contours, respectively. Apparent oxygen utilization (oxygen saturation for observed temperature and salinity minus the measured oxygen concentrations) is marked with thick dashed black contours ( -45 to $-15 \mu \mathrm{mol} / \mathrm{kg})$. Isopycnals $\left(24.2,25,25.5\right.$, and $\left.26 \mathrm{~kg} / \mathrm{m}^{3}\right)$ are shown as grey contours. 

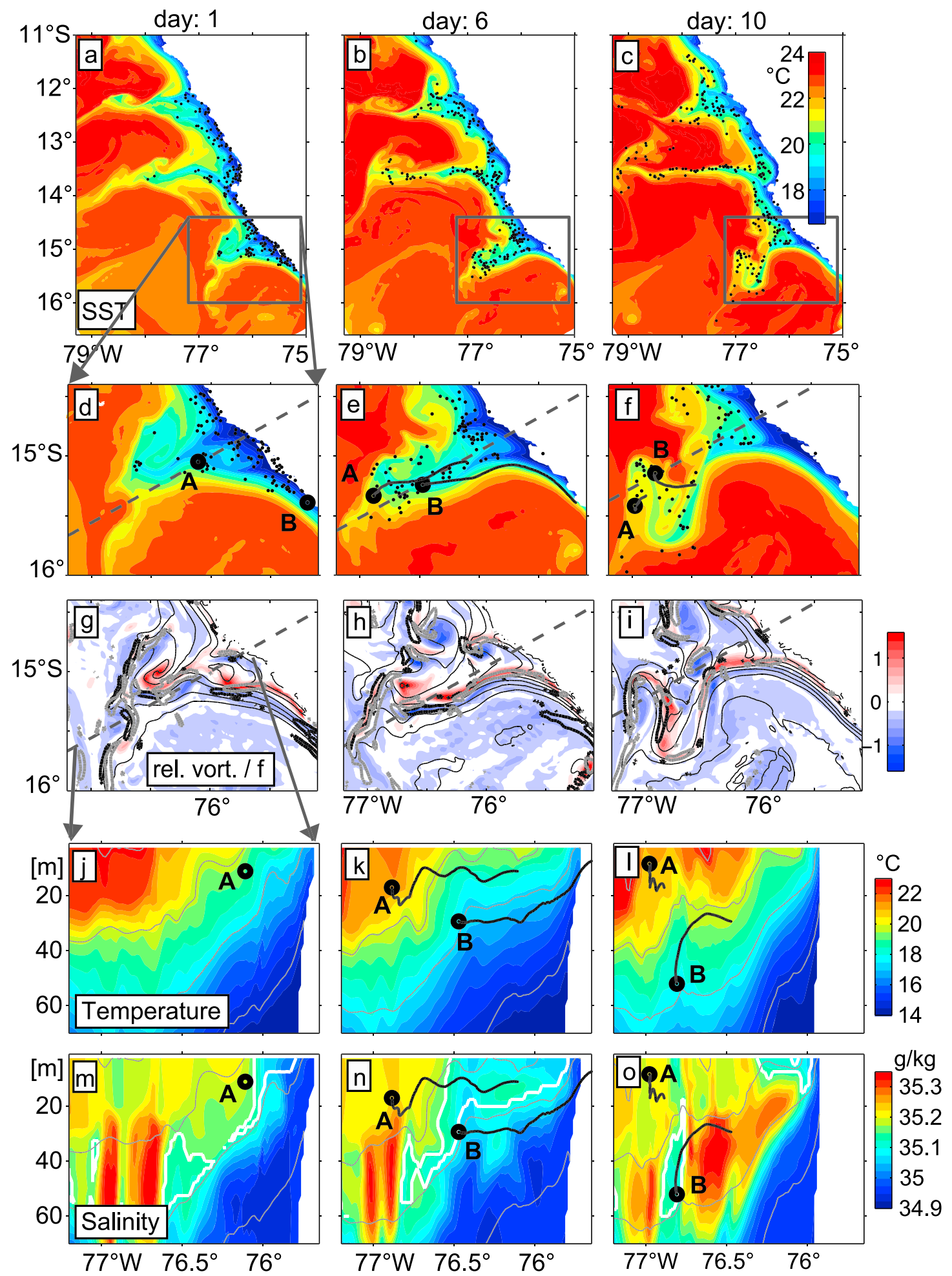

Figure 3. (a-f) The modeled SST at days 1,6 , and 10 including example float positions. The floats are seeded at day 0 below the mixed layer and upwell during day 1 (more details in section 2.2). (g-i) The vertical component of the relative vorticity $\left(\zeta_{z}=v_{x}-u_{y}\right.$, where $u_{y}$ and $v_{x}$ are the spatial derivatives of the horizontal velocities $u$ and $v$ in $y$ and $x$ directions, respectively) scaled with the Coriolis parameter $\mathrm{f}$ (color shading), downward velocities ( $w=6.5 \mathrm{~m} / \mathrm{d}$, grey contour), and the magnitude $\left(F_{s}=1.5 \cdot 10^{-14} \mathrm{~s}^{-5}\right.$, black contour) of the frontogenesis function $\left(F_{s}=-\left(u_{x} b_{x}+v_{x} b_{y}, u_{y} b_{x}+v_{y} b_{y}\right) \cdot \nabla_{h} b\right.$, where $\nabla_{h}$ is the horizontal gradient operator and $b=-g \rho / \rho_{0}$ is the buoyancy, with $g$ being the gravitational acceleration, $\rho$ the density, and $\rho_{0}$ a reference density) both at $15 \mathrm{~m}$ depth. The (j-I) temperature and $(\mathrm{m}-\mathrm{o})$ salinity distributions of the upper $70 \mathrm{~m}$ of the water column. The white contours indicate water masses with temperatures between 17.6 and $20^{\circ} \mathrm{C}$ and salinities below 35.17 practical salinity unit. The position of two example floats A (stays in mixed layer) and B (is subducted) are shown by thick black dots. The black tails indicate their pathway since the previously shown position. The filament evolves as the observed one (Figure 2 ) in mid-January. 
variability such as filaments and fronts in the SST distribution as seen in the observations (Figures $1-3$ ). The model shows slightly colder temperatures $\left(\sim 1^{\circ} \mathrm{C}\right)$ compared to the observations.

To study the circulation of newly upwelled water, virtual floats are advected offline by the $4 \mathrm{~h}$ average modeled flow using the ROMS offline tool [Carret al., 2008; Capet et al., 2004]. Fifty thousand virtual floats are seeded randomly between 78 and $75^{\circ} \mathrm{W}$ and 16 and $12^{\circ} \mathrm{S}$ in the upper $50 \mathrm{~m}$ and $150 \mathrm{~m}$ of the water column, respectively, in summer and winter. Floats were released at time $t=0$ and are advected forward for 1 day (Figure 3). All floats which enter the mixed layer during this day (thus representative of newly upwelled water) and have densities above $25 \mathrm{~kg} / \mathrm{m}^{3}$ and $25.75 \mathrm{~kg} / \mathrm{m}^{3}$, respectively, in summer and winter, are selected. This procedure explains the spatially inhomogenous distribution of the float positions at day 1 , which are more abundant in areas of strong upwelling (Figures 3a-3c). Starting at day 1 all floats are advected forward in time until day 20. For each of the 4 model years, 10 float experiments at 10 consecutive starting days are carried out per season with a random subsample of 100 float. Thus in total 8000 floats (4000 per season) pathways are analyzed.

\section{Results}

\subsection{Observed Subduction of Surface Water in a Submesoscale Cold Filament}

The formation and decay of a submesoscale cold filament is captured by satellite and glider-based observations off Peru near $14^{\circ} \mathrm{S}$ (Figures $1 \mathrm{a}$ and 2). The temporal evolution of the SST is shown in Figures $2 \mathrm{a}-2 \mathrm{~d}$. Two distinct water mass features are present in the upper $40 \mathrm{~m}$ of the water column in the observations. Low-salinity $(35.05-35.24 \mathrm{~g} / \mathrm{kg})$ features are found at temperatures ranges between 16.75 and $20^{\circ} \mathrm{C}$, and high oxygen $\left(>245 \mu \mathrm{mol} / \mathrm{kg}\right.$ ) features are present in slightly warmer waters $\left(17.5-22^{\circ} \mathrm{C}\right)$ indicated in black and white contours, respectively (Figures $2 i-2 l$ and $2 m-2 p$ ). In the following we use these distinct water mass characteristics to learn about the evolution of these features during the formation and decay of the filament.

Both low-salinity and high oxygen concentrations are found close to the surface above $10 \mathrm{~m}$ depth during the formation of the filament (Figures $2 \mathrm{i}$ and $2 \mathrm{~m}$ ). The high oxygen concentrations result both from equilibration with atmosphere and biological production. The $245-250 \mu \mathrm{mol} / \mathrm{kg}$ oxygen in newly upwelled waters may be explicable by pure air-sea gas exchange given the temperature and salinity range of $\left(17-18^{\circ} \mathrm{C}\right.$, $35.15-35.2 \mathrm{~g} / \mathrm{kg}$ ) observed during the whole glider deployment near the coast during upwelling. However, our observations show oxygen concentrations above $250 \mu \mathrm{mol} / \mathrm{kg}$ (locally $>280 \mu \mathrm{mol} / \mathrm{kg}$, Figure $2 \mathrm{~m}$ ) pointing to oxygen production by phytoplankton blooming in the upwelled waters as indicated by high chlorophyll fluorescence of $20 \mu \mathrm{g} / \mathrm{L}$ (Figure $2 \mathrm{q}$ ).

Four days later the filament is fully developed (Figure $2 \mathrm{~b}$ ) and salinity and oxygen features with similar characteristics are found $90-120 \mathrm{~km}$ offshore at 10 to $20 \mathrm{~m}$ depth (Figures $2 \mathrm{j}$ and $2 \mathrm{n}$ ). After the decay of the filament and the relaxation of the upwelling front the salinity and oxygen features are found at around $25 \mathrm{~m}$ depth 75-100 km offshore (Figures $2 \mathrm{l}$ and $2 \mathrm{p}$ ). We estimate a net oxygen production at this depth of 4-9 $\mu \mathrm{mol} / \mathrm{kg}$ using observed chlorophyll concentrations $(2-4 \mu \mathrm{g} / \mathrm{L}$, Figure $2 \mathrm{t})$, a chlorophyll to carbon ratio for the Peruvian upwelling regime of 0.02 [Behrenfeld et al., 2005] and a photosynthetic quotient of 1.4 [Laws, 1991] and assuming 30\% light reduction. However, the oxygen anomalies are associated with apparent oxygen utilization between -45 and $-15 \mu \mathrm{mol} / \mathrm{kg}$ (black dashed contour in Figure $2 \mathrm{p}$ ), which can be explained by much higher net oxygen production of 33-44 $\mu \mathrm{mol} / \mathrm{kg}$ near the surface where chlorophyll concentrations of $15-20 \mu \mathrm{g} / \mathrm{L}$ are observed (Figure $2 q$ ). These observations suggest that the water masses are subducted within the filament. An important finding is that the subduction of the highly oxygenated water reaches into the oxycline but not into the $O M Z$ core ( $<1 \mu \mathrm{mol} / \mathrm{kg}$ oxygen) (Figure $2 \mathrm{p}$ ).

Due to alongshore advection and the three-dimensional nature of the subduction process, our observations likely do not capture the same water masses at each transect. However, water with similar hydrographic characteristics is upwelled along the Peruvian coastline (Figures 1 and 2), which justifies our two-dimensional analysis. To broaden the scope of the analysis, we make use of a three-dimensional model which simulates submesoscale filaments, enabling to study the pathways and characteristics of a large number of subducted water parcels.

\subsection{Modeled Subduction of Newly Upwelled Water}

The evolution of a simulated filament, which forms in mid-January and has horizontal scales of $\mathrm{O}(100 / 10 \mathrm{~km}$, length/width) as the observed filament (Figure 2), is described to illustrate the capability of the model to simulate subduction in cold filaments (Figure 3). Salinity intrusions of horizontal $\mathrm{O}(10 \mathrm{~km})$ and vertical $\mathrm{O}(20 \mathrm{~m})$ scales are simulated by the model reaching down to about $60 \mathrm{~m}$ depth (Figures $3 \mathrm{~m}-30$ ). The observed salinity 
structures show horizontal and vertical scales of the same order (Figures $2 \mathrm{i}-2 \mathrm{l}$ ) but reach only to about $40 \mathrm{~m}$ depth. The difference might be related to the slightly too broad thermocline in the model but could also be due to the fact that we only compare two snapshots in highly turbulent flow. The model captures the high salinity water mass (Figures 3m-3o) associated with the offshore subtropical surface water [Fiedler and Talley, 2006], which is also seen in the glider observations (Figures $3 \mathbf{i}-3 \mathbf{l}$ ).

Downward velocities of up to $45 \mathrm{~m} / \mathrm{d}$ are simulated within the cold filament (Figures $3 \mathrm{~g}-3 \mathrm{i}$ ) especially in areas of enhanced cyclonic relative vorticity (Figures $3 g-3 i$ ). The frontogenesis function is calculated following Hoskins and Bretherton [1972] to investigate the driving mechanism for the vertical velocities (see caption of Figure 3 for calculation). At the temperature fronts, associated with the cold filament, enhanced values of the frontogenesis function suggest that the vertical velocities are indeed driven by frontogenesis (Figures $3 g-3 i)$. The most intense subduction occurs in a narrow band on the cold side of the temperature fronts (Figures 3d-3i) as already pointed out by earlier studies [e.g., Mahadevan and Tandon, 2006; Capet et al., 2008b; Nagai et al., 2015]. These analysis supports our interpretation that the observed and modeled tracer structures result from downward motion within the cold filaments as expected from cold filamentary intensification [McWilliams et al., 2009; Gula et al., 2014; McWilliams et al., 2015].

The model simulates subduction in filaments with horizontal and vertical scales and hydrography comparable to our observations. Thus, we carry out numerical Lagrangian diagnostics to investigate whether subduction is regularly active, how it compares to the magnitude of upwelling, and whether its observed depth is representative of summer conditions. The horizontal float positions at day 1 for a typical Lagrangian experiment are shown in Figure $3 a$ together with the simulated SST. At this time all floats are in the mixed layer, which is typically around $15 \mathrm{~m}$ deep near the coast in summer. During the following days the floats can take two different pathways, which are shown with example trajectories of floats $A$ and $B$ in Figure 3. Float $A$ remains within the mixed layer and crosses several isopycnals thus reaching lower densities during its offshore movement (Figure 3). In contrast, float B is subducted mainly along isopycnals and reaches $55 \mathrm{~m}$ depth after 10 days of drift (Figures 3i and 3l).

A large portion of the floats move offshore in cold filaments (Figures $3 b$ and 3c). A synthetic view of the subducted water mass pathways taking into account all the cold filaments that are present in mid-January to mid-February in four consecutive model years is shown in Figure 4. The maximum subduction depth of about $65 \mathrm{~m}$ (Figure 4e) is reached within a few days (Figure 4a). Floats that stay in the mixed layer while moving offshore tend to get lighter and cross isopycnals as they warm (Figure 4c). In summer more than $99.5 \%$ of the floats become lighter during their time in the mixed layer (Figures 4c, 4e, and $4 \mathrm{~g}$ ) due to strong surface heating occurring off Peru. In contrast, the floats that are subducted tend to keep their density (Figure 4c). The less time they spend in the warming mixed layer while moving offshore, the deeper they are subducted (Figure 4e). In particular, the amount of buoyancy gain (e.g., due to atmospheric warming and lateral mixing with warmer offshore waters) is crucial for the final subduction depth (Figure 4e).

The simulation-based results help to interpret the glider observations. The latter demonstrate the absence of highly oxygenated waters below $30 \mathrm{~m}$ depth (Figures 20 and $2 \mathrm{p}$ ). This can be explained by the fact that it takes several days until the upwelled oxygen-depleted water becomes oxygen enriched by both air-sea gas exchange and oxygen production by a phytoplankton bloom (Figures $2 \mathrm{~m}$ and $2 \mathrm{q}$ ). During this time the waters are found close to the surface and they gradually warm while they are advected offshore. This implies that the subduction of newly upwelled water cannot reach into the density range of the OMZ during summer. However, the oxycline is indeed ventilated by this rapid subduction process as the newly upwelled water carries a large amount of oxygen once it has either equilibrated to the atmosphere or received oxygen by photosynthesis (Figure 2p).

In order to see how much of the newly upwelled water is subducted within a few days, we separated the simulated floats into the ones which stay in the mixed layer (e.g., float A) and those which are subducted (e.g., float B) (Figure 3). The temporal evolution of the mixed layer float inventory is shown in Figure $4 \mathrm{~h}$. The short-term oscillations of the inventory result from the diurnal cycle of the mixed layer depth driven by diurnal surface forcing (i.e., diurnal cycle of the incoming solar flux). We vary the starting day of the float release and carried out the same diagnostic in four different years of the model quasi-equilibrium solution to test for robustness. A relatively stable fraction of $50 \%$ of the floats is subducted within about 5 days. This implies that $50 \%$ of the newly upwelled water leaves the mixed layer within about 5 days and ventilates the oxycline. 
(a) summer

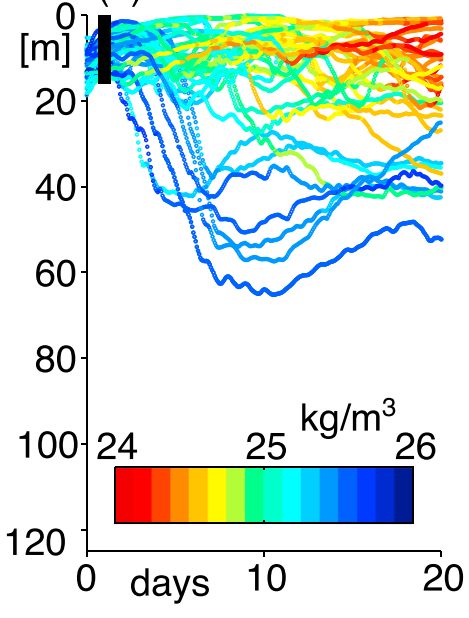

(b) winter

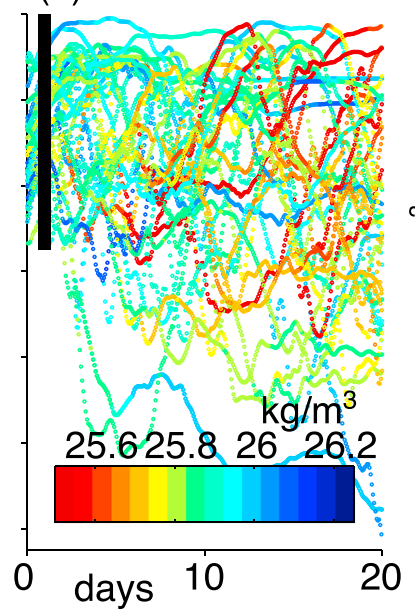

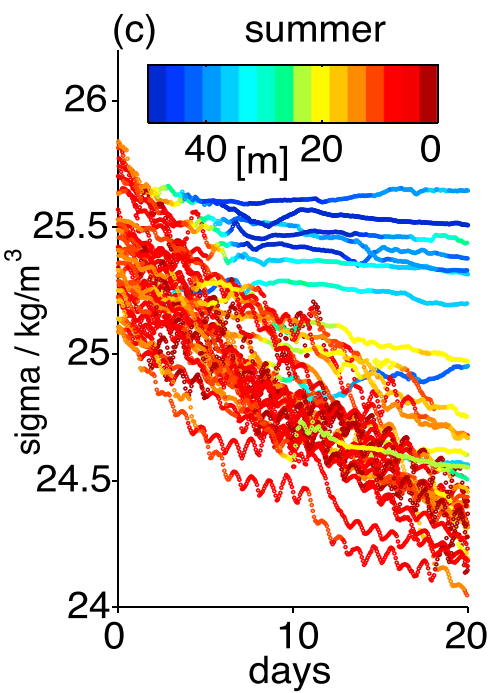

(d) winter
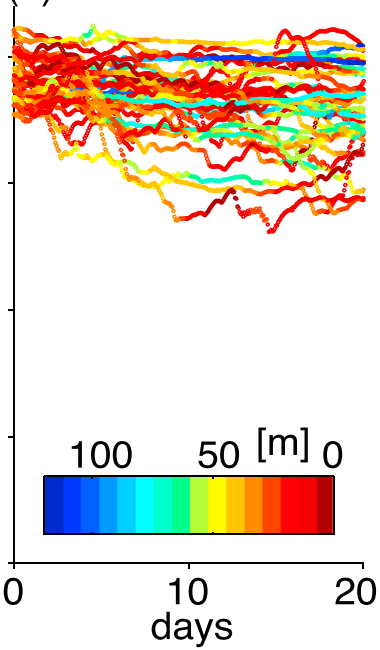

final subduction depth

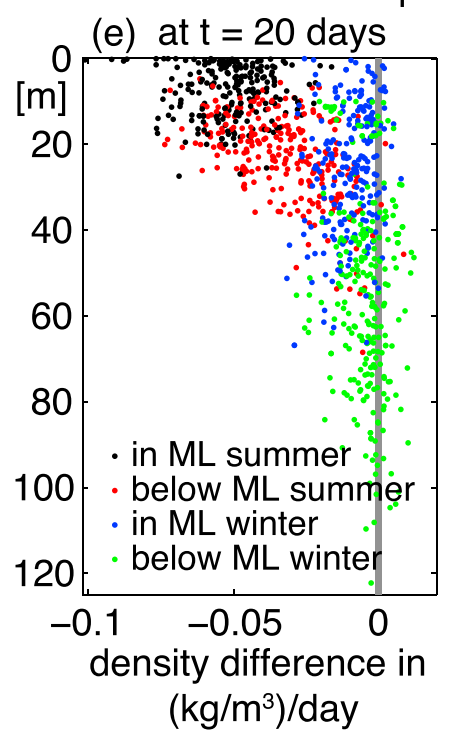

(f) pdf - depth

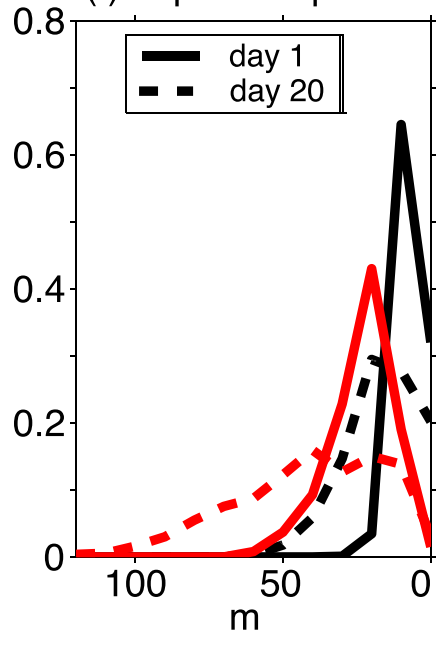

(g) pdf - pot. density

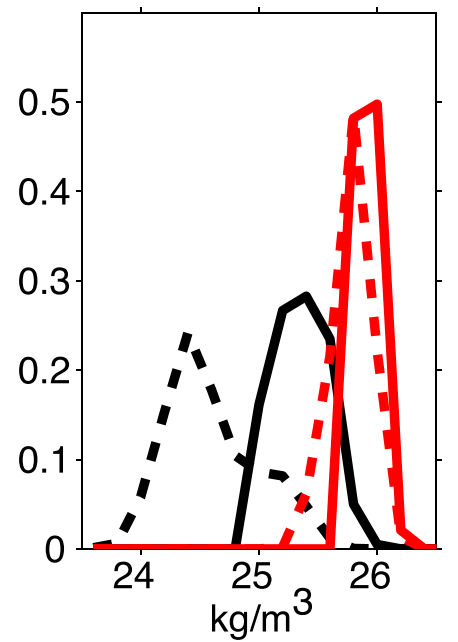

(h)

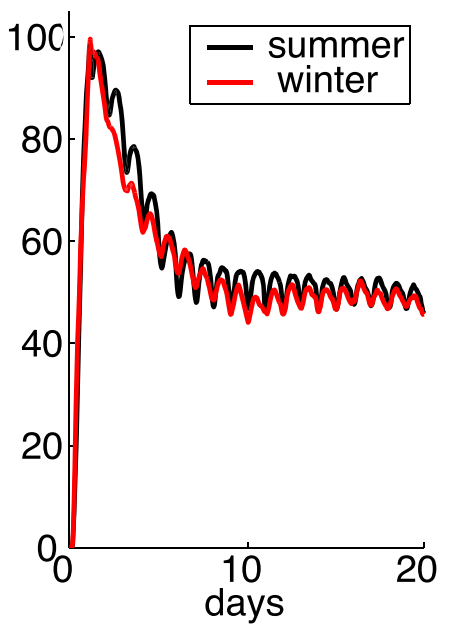

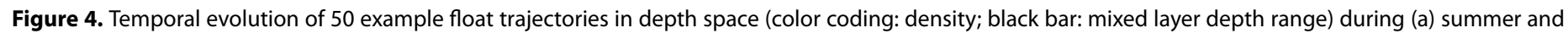

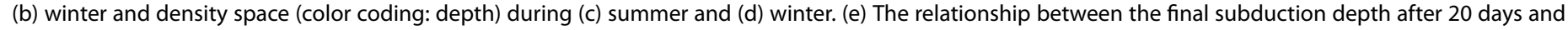

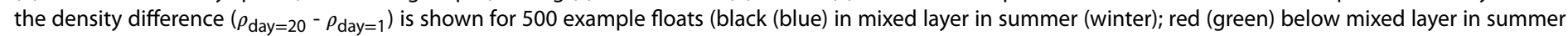

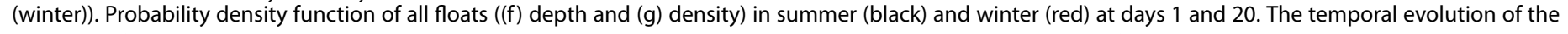

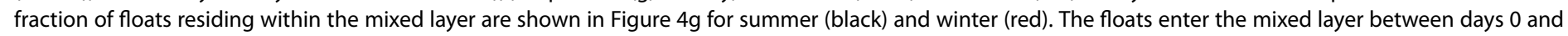
1 and are advected forward in time until day 20.

\section{Discussion and Conclusion}

Observational evidence for the subduction of newly upwelled, well-oxygenated surface water within a submesoscale cold filament off Peru is given. Lagrangian diagnostics in a submesoscale-permitting numerical model simulation support the interpretation of the observations. The subduction ventilates the upper oxycline but does not reach into the OMZ itself during summer. This is because the newly upwelled waters gain buoyancy due to surface heating and thus cannot be subducted into the density range of OMZ core waters.

The upper boundary of the Peruvian OMZ is characterized by high oxygen consumption rates primarily due to high heterotrophic microbial activity sustained by the downward flux of organic matter [Revsbech et al., 2009; Kalvelage et al., 2015]. The oxygen consumption rates measured by Kalvelage et al. [2015] could not be balanced by their simple one-dimensional diffusion model estimate. This points to the importance of along-isopycnal eddy-driven oxygen supply [Colas et al., 2013; Thomsen et al., 2016] to meet the high oxygen demand of aerobic remineralization processes. 
Given that our model does not fully resolve the submesoscale regime, we expect that the vertical exchange intensity is probably underestimated at this resolution [Capet et al., 2008b]. Vertical exchange processes such as symmetric instabilities [Haine and Marshall, 1998], which act on lateral scales of some hundreds of meters, are not resolved. Also, the effects of high-frequency winds and atmosphere-ocean coupling are not included as our monthly climatologically forced simulations. For example, if local winds are aligned with submesoscale fronts, Ekman buoyancy fluxes might lead to a deeper subduction depth [Thomas and Lee, 2005]. However, given that the winds are relatively steady off Peru [Oerder et al., 2016], we assume that these effects on the behavior of the floats are minor.

A model study in the Gulf Stream region [Gula et al., 2014] and a combined multiplatform observational/ biogeochemical model study in the subpolar North Atlantic [Omand et al., 2015] highlight the importance of submesoscale eddy-driven export of surface waters into the ocean interior. In both studies much larger subduction depths ( 250-300 m) than those reported here are reached. In Gula et al. [2014] this might be related to the density front of the Gulf Stream which reaches much deeper than that off Peru and thus allows much deeper along-isopycnal pathways. The vertical scale of a front is crucial for vertical penetration of submesoscale eddy fluxes [Ramachandran et al., 2014]. Second, the water is cooled at the surface in the Gulf stream region, resulting in a density increase and thus greater subduction depths [Gula et al., 2014]. This contrasts with the summer situation presented here and indicates that subduction depths might increase during winter in the region.

To further investigate the seasonal variability of subduction, we carry out a float experiment in winter (mid-June to mid-July), when surface cooling occurs. Indeed, we find much deeper subduction depths of up to $120 \mathrm{~m}$ off Peru in the model (Figures $4 \mathrm{~b}$ and $4 \mathrm{f}$ ). This can be partly explained by the deeper mixed layer (up to $65 \mathrm{~m}$ ) in winter (Figures $4 \mathrm{e}$ and $4 \mathrm{f}$ ) and by the cooling of the upwelled waters (Figure $4 \mathrm{~g}$ ). While in summer less than $0.5 \%$ of the floats become denser, in winter around $15 \%$ experience a buoyancy loss and most floats mainly keep their initial density (Figure $4 \mathrm{~g}$ ). The absence of strong warming after the upwelling event in winter thus allows ventilation along isopycnals to deeper depth. Thus, submesoscale processes may ventilate the upper part of the $\mathrm{OMZ}$ during winter. However, as high-resolution measurements in winter are missing, further observations are necessary to test this hypothesis. In particular, a seasonal cycle of the oxygen distribution exists off Peru, which includes variations in the depth and vertical structure of the oxycline [Czeschel et al., 2015]. Consequently, we advocate for the collection of additional high-resolution physical-biogeochemical observations at different seasons. Guided by these observations submesoscale-permitting physical-biogeochemical model simulations should be carried out to further understand the role of submesoscale frontal processes for the oxygen ventilation off Peru.

Acknowledgments

This work is a contribution of the Sonderforschungsbereich 754 “Climate-Biogeochemistry Interactions in the Tropical Ocean" (www.sfb754.de), which is funded by the Deutsche Forschungsgemeinschaft (DFG). We are grateful to the Peruvian authorities for the permission to carry out scientific work in their national waters. Special thanks go to the captain and the crew of the R/V Meteor for their support during the M92 and M93 cruises. We thank three anonymous reviewers for helpful suggestions to improve the manuscript. The used data sets are stored on the Kiel Ocean Science Information System (OSIS, https://portal.geomar.de/ kdmi, datamanagement@geomar.de) and can be accessed upon request. According to the SFB 754 data policy https://www.sfb754.de/de/data, all data associated with this publication will be published at a world data center (www.pangaea.de, search project:sfb754) when the paper is accepted and published.
Filaments and fronts are common features within eastern boundary upwelling systems, all of which encompass large OMZs. However, most state-of-the-art large- and regional-scale physical-biogeochemical ocean models do not resolve submesoscale fronts and filaments and the associated downward transport of oxygen and other tracers. Even if the subduction event observed off Peru only reaches into the oxygenated part of the thermocline, the associated ventilation mechanism likely influences the shape and depth of the upper boundary of OMZs, which would probably be shallower without this process.

\section{References}

Barth, J. A., T. J. Cowles, P. M. Kosro, P. K. Shearman, H. Huyer, and R. L. Smith (2002), Injection of carbon from the shelf to offshore beneath the euphotic zone in the California current, J. Geophys. Res., 107(C6), 10-1-10-8, doi:10.1029/2001JC000956.

Barton, E. D., J. Arstegui, P. Tett, and E. Navarro-Prez (2004), Variability in the Canary Islands area of filament-eddy exchanges,

Prog. Oceanogr., 62(2-4), 71-94, doi:10.1016/j.pocean.2004.07.003, the Canary Islands Coastal Transition Zone - Upwelling, Eddies and Filaments.

Behrenfeld, M. J., E. Boss, D. A. Siegel, and D. M. Shea (2005), Carbon-based ocean productivity and phytoplankton physiology from space, Global Biogeochem. Cycles, 19, GB1006, doi:10.1029/2004GB002299.

Boccaletti, G., R. Ferrari, and B. Fox-Kemper (2007), Mixed layer instabilities and restratification, J. Phys. Oceanogr., 37(9), 2228-2250, doi:10.1175/JPO3101.1.

Capet, X., F. Colas, J. C. Mcwilliams, P. Penven, and P. Marchesiello (2008a), Eddies in eastern boundary subtropical upwelling systems, in Ocean Modeling in an Eddying Regime, edited by M. W. Hecht and H. Hasumi, pp. 131-147, AGU, Washington, D. C.

Capet, X., J. C. McWilliams, M. J. Molemaker, and A. F. Shchepetkin (2008b), Mesoscale to submesoscale transition in the California current system. Part II: Frontal processes, J. Phys. Oceanogr., 38(1), 44-64, doi:10.1175/2007JPO3672.1.

Capet, X. J., P. Marchesiello, and J. C. McWilliams (2004), Upwelling response to coastal wind profiles, Geophys. Res. Lett., 31, L13311, doi:10.1029/2004GL020123. 
Carr, S. D., X. J. Capet, J. C. McWilliams, J. T. Pennington, and F. Chavez (2008), The influence of diel vertical migration on zooplankton transport and recruitment in an upwelling region: Estimates from a coupled behavioral-physical model, Fish. Oceanogr., 17(1), 1-15, doi:10.1111/j.1365-2419.2007.00447.x.

Chaigneau, A., N. Dominguez, G. Eldin, L. Vasquez, R. Flores, C. Grados, and V. Echevin (2013), Near-coastal circulation in the Northern Humboldt Current System from shipboard ADCP data, J. Geophys. Res. Oceans, 118, 5251-5266, doi:10.1002/jgrc.20328.

Colas, F., J. C. McWilliams, X. Capet, and J. Kurian (2012), Heat balance and eddies in the Peru-Chile current system, Clim. Dyn., 39(1-2), 509-529, doi:10.1007/s00382-011-1170-6.

Colas, F., X. Capet, J. C. McWilliams, and Z. Li (2013), Mesoscale eddy buoyancy flux and eddy-induced circulation in eastern boundary currents, J. Phys. Oceanogr., 43(6), 1073-1095, doi:10.1175/JPO-D-11-0241.1.

Cravo, A., P. Relvas, S. Cardeira, F. Rita, M. Madureira, and R. Sánchez (2010), An upwelling filament off southwest lberia: Effect on the chlorophyll a and nutrient export, Cont. Shelf Res., 30(15), 1601-1613, doi:10.1016/j.csr.2010.06.007.

Czeschel, R., L. Stramma, R. A. Weller, and T. Fischer (2015), Circulation, eddies, oxygen, and nutrient changes in the eastern tropical South Pacific Ocean, Ocean Sci., 11(3), 455-470, doi:10.5194/os-11-455-2015.

Fiedler, P. C., and L. D. Talley (2006), Hydrography of the eastern tropical pacific: A review, Prog. Oceanogr., 69(2-4), 143-180, doi:10.1016/j.pocean.2006.03.008, a Review of Eastern Tropical Pacific Oceanography.

Flament, P., L. Armi, and L. Washburn (1985), The evolving structure of an upwelling filament, J. Geophys. Res., 90(C6), 11,765-11,778, doi:10.1029/JC090iC06p11765.

Gruber, N., Z. Lachkar, H. Frenzel, P. Marchesiello, M. Munnich, J. C. McWilliams, T. Nagai, and G.-K. Plattner (2011), Eddy-induced reduction of biological production in eastern boundary upwelling systems, Nat. Geosci., 4(11), 787-792.

Gula, J., M. J. Molemaker, and J. C. McWilliams (2014), Submesoscale cold filaments in the gulf stream, J. Phys. Oceanogr., 44(10), 2617-2643, doi:10.1175/JPO-D-14-0029.1.

Haine, T. W. N., and J. Marshall (1998), Gravitational, symmetric, and baroclinic instability of the ocean mixed layer, J. Phys. Oceanogr., 28(4), 634-658, doi:10.1175/1520-0485(1998)028<0634:GSABIO>2.0.CO;2.

Hamersley, M. R., G. Lavik, D. Woebken, J. E. Rattray, E. C. Hopmans, and J. S. Sinninghe (2007), Anaerobic ammonium oxidation in the Peruvian oxygen minimum zone, Limnol. Oceanogr., 52(3), 923-933, doi:10.4319/lo.2007.52.3.0923.

Hoskins, B. J., and F. P. Bretherton (1972), Atmospheric frontogenesis models: Mathematical formulation and solution, J. Atmos. Sci., 29(1), 11-37, doi:10.1175/1520-0469(1972)029<0011:AFMMFA>2.0.CO;2.

Kadko, D. C., L. Washburn, and B. Jones (1991), Evidence of subduction within cold filaments of the Northern California coastal transition zone, J. Geophys. Res., 96(C8), 14,909-14,926, doi:10.1029/91JC00885.

Kalvelage, T., G. Lavik, P. Lam, S. Contreras, L. Arteaga, C. R. Loscher, A. Oschlies, A. Paulmier, L. Stramma, and M. M. M. Kuypers (2013), Nitrogen cycling driven by organic matter export in the South Pacific oxygen minimum zone, Nat. Geosci., 6(3), $228-234$.

Kalvelage, T., et al. (2015), Aerobic microbial respiration in oceanic oxygen minimum zones, PLoS ONE, 10(7), e0133526.

Karstensen, J., L. Stramma, and M. Visbeck (2008), Oxygen minimum zones in the eastern tropical Atlantic and Pacific Oceans, Prog. Oceanogr., 77(4), 331-350, doi:10.1016/j.pocean.2007.05.009.

Lathuilière, C., V. Echevin, M. Lévy, and G. Madec (2010), On the role of the mesoscale circulation on an idealized coastal upwelling ecosystem, J. Geophys. Res., 115, C09018, doi:10.1029/2009JC005827.

Laws, E. A. (1991), Photosynthetic quotients, new production and net community production in the open ocean, Deep Sea Res. Part A, 38(1), 143-167, doi:10.1016/0198-0149(91)90059-O.

Lutjeharms, J. R. E., F. A. Shillington, and C. M. D. Rae (1991), Observations of extreme upwelling filaments in the southeast Atlantic Ocean, Science, 253(5021), 774-776, doi:10.1126/science.253.5021.774.

Mahadevan, A., and A. Tandon (2006), An analysis of mechanisms for submesoscale vertical motion at ocean fronts, Ocean Modell., 14(3-4), 241-256, doi:10.1016/j.ocemod.2006.05.006.

McWilliams, J. C. (2016), Submesoscale currents in the ocean, Proc. R. Soc. A, 472, 2189, doi:10.1098/rspa.2016.0117.

McWilliams, J. C., F. Colas, and M. J. Molemaker (2009), Cold filamentary intensification and oceanic surface convergence lines, Geophys. Res. Lett., 36, L18602, doi:10.1029/2009GL039402.

McWilliams, J. C., J. Gula, M. J. Molemaker, L. Renault, and A. F. Shchepetkin (2015), Filament frontogenesis by boundary layer turbulence, J. Phys. Oceanogr., 45, 1988-2005, doi:10.1175/JPO-D-14-0211.1.

Nagai, T., N. Gruber, H. Frenzel, Z. Lachkar, J. C. McWilliams, and G.-K. Plattner (2015), Dominant role of eddies and filaments in the offshore transport of carbon and nutrients in the California current system, J. Geophys. Res. Oceans, 120, 5318-5341, doi:10.1002/2015JC010889.

Oerder, V., F. Colas, V. Echevin, S. Masson, C. Hourdin, S. Jullien, G. Madec, and F. Lemarié (2016), Mesoscale SST-wind stress coupling in the Peru-Chile current system: Which mechanisms drive its seasonal variability?, Clim. Dyn.,1-22, doi:10.1007/s00382-015-2965-7.

Omand, M. M., E. A. D'Asaro, C. M. Lee, M. J. Perry, N. Briggs, I. Cetini, and A. Mahadevan (2015), Eddy-driven subduction exports particulate organic carbon from the spring bloom, Science, 348(6231), 222-225, doi:10.1126/science.1260062.

Pietri, A., P. Testor, V. Echevin, A. Chaigneau, L. Mortier, G. Eldin, and C. Grados (2013), Finescale vertical structure of the upwelling system off southern Peru as observed from glider data, J. Phys. Oceanogr., 43(3), 631-646, doi:10.1175/JPO-D-12-035.1.

Ramachandran, S., A. Tandon, and A. Mahadevan (2014), Enhancement in vertical fluxes at a front by mesoscale-submesoscale coupling, J. Geophys. Res. Oceans, 119, 8495-8511, doi:10.1002/2014JC010211.

Revsbech, N. P., L. H. Larsen, J. Gundersen, T. Dalsgaard, O. Ulloa, and B. Thamdrup (2009), Determination of ultra-low oxygen concentrations in oxygen minimum zones by the stox sensor, Limnol. Oceanogr. Methods, 7(5), 371-381, doi:10.4319/lom.2009.7.371.

Risien, C. M., and D. B. Chelton (2008), A global climatology of surface wind and wind stress fields from eight years of quikscat scatterometer data, J. Phys. Oceanogr., 38(11), 2379-2413, doi:10.1175/2008JPO3881.1.

Rossi, V., C. López, J. Sudre, E. Hernández-García, and V. Garçon (2008), Comparative study of mixing and biological activity of the Benguela and Canary upwelling systems, Geophys. Res. Lett., 35(11), L11602, doi:10.1029/2008GL033610.

Rossi, V., C. López, E. Hernández-García, J. Sudre, V. Garçon, and Y. Morel (2009), Surface mixing and biological activity in the four eastern boundary upwelling systems, Nonlinear Processes Geophys., 16(4), 557-568, doi:10.5194/npg-16-557-2009.

Shchepetkin, A. F., and J. C. McWilliams (2005), The regional oceanic modeling system (ROMS): A split-explicit, free-surface, topography-following-coordinate oceanic model, Ocean Modell., 9(4), 347-404, doi:10.1016/j.ocemod.2004.08.002.

Shchepetkin, A. F., and J. C. McWilliams (2009), Correction and commentary for "Ocean forecasting in terrain-following coordinates: Formulation and skill assessment of the regional ocean modeling system" by Haidvogel et al., j. comp. phys. 227, pp. 3595-3624, J. Comput. Phys., 228(24), 8985-9000, doi:10.1016/j.jcp.2009.09.002.

Strub, P. T., P. M. Kosro, and A. Huyer (1991), The nature of the cold filaments in the California current system, J. Geophys. Res. Oceans, 96(C8), 14,743-14,768, doi:10.1029/91JC01024. 
Thomas, L. N., and C. M. Lee (2005), Intensification of ocean fronts by down-front winds, J. Phys. Oceanogr., 35(6), 1086-1102, doi:10.1175/JPO2737.1.

Thomas, L. N., A. Tandon, and A. Mahadevan (2008), Submesoscale processes and dynamics, in Ocean Modeling in an Eddying Regime, edited by M. W. Hecht and H. Hasumi, pp. 17-38, AGU, Washington, D. C., doi:10.1029/177GM04.

Thomsen, S., T. Kanzow, G. Krahmann, R. J. Greatbatch, M. Dengler, and G. Lavik (2016), The formation of a subsurface anticyclonic eddy in the Peru-Chile undercurrent and its impact on the near-coastal salinity, oxygen, and nutrient distributions, J. Geophys. Res. Oceans, 121, 476-501, doi:10.1002/2015JC010878. 